\title{
BOEKBESPREKINGEN
}

\section{TOT DE ORDE GEROEPEN}

Opstellenbundel ter gelegenheid van het veertigjarig bestaan der Vereniging van Academisch Gevormde Accountants op 23 april 1967.

Uitgave Æ. E. Kluwer, Deventer 1967; 215 blz.; prijs $f 22,50$.

\section{door Drs. I. Kleerekoper}

De redactiecommissie, bestaande uit de heren Prof. Drs. R. Burgert, Prof. Drs. A. A. de Jong, Dr. A. C. M. van Keep en Drs. J. G. de Weger verdient allereerst een bijzonder woord van lof voor de titel, die aan deze bundel opstellen door haar werd meegegeven. Het samenvallen van het 40 -jarig bestaan van de V.A.G.A. met de inbreng van de activiteiten dezer beroepsorganisatie in het Nederlands Instituut van Registeraccountants (een publiekrechtelijke Orde) kon naar ik meen niet beter en kernachtiger tot uitdrukking gebracht worden dan met deze titel is geschied. Voorwaar: een trouvaille!

Zoals het een accountant past zou ik gaarne mijn oordeel over deze bundel-als-geheel vooraf laten gaan aan de bespreking der afzonderlijke opstellen. Dit oordeel luidt, dat de redactie-commissie een gelukkige hand blijkt te hebben gehad bij de keuze der auteurs; de bijdragen bestrijken namelijk een groot veld van kennis en ervaring op en rond het werkterrein van de accountant; de opstellen zijn voorts beurtelings van samenvattende, instructieve, probleemstellende of discussie-uitlokkende aard; zij vormen daardoor cen combinatie die - bij alle verschil in appreciatie welke men voor de afzonderlijke bijdragen moge hebben - toch voor elke lezer en bezitter van de bundel een belangwekkend stuk Nederlandse literatuur op het daarvan schaars voorziene terrein der accountancy betekent. Daarmee is, naar het mij voorkomt, de redactiecommissie - en zijn zodoende ook de 15 auteurs - in de opzet om de gedachte aan de V.A.G.A. te doen voortleven, op gelukkige wijze geslaagd.

De bundel is ingedeeld in 6 opstellen Bedrijfseconomie, 2 opstellen Administratieve Organisatie, 5 opstellen Accountantscontrole en 1 opstel Belastingrecht. De totaal-controle levert aldus een ist-positie van 14 opstellen op, terwijl van een soll-positie van 15 moet worden uitgegaan. Het ontbrekende opstel is buiten de voornoemde indeling gebleven; het is een bijdrage van Prof. Drs. J. Brands onder de ritel "Associaties van Accountants. Accountant-Commissaris", waarmee de bundel wordt geopend. Brands behandelt eerst het verschijnsel van accountantspraktijken, die in het kader van de continuïteitsverzorging gebruik blijven maken van een naamsaanduiding voor de maatschap, waarin namen van reeds uitgetreden of overleden oprichters blijven voorkomen. Dit verschijnsel worde door de auteur op studentikoos-satirische wijze gedemonstreerd aan de hand van een uitvoerige schildering van de lotgevallen van een pseudomaatschap. Brands maakt nu een aantal gedachtensprongen: continuïteit over het leven der individuele beroepsbeoefenaren heen is bedrijfsuitoefening; bedrijfsuitoefening vraagt de N.V.-vorm; deze vorm is best te regelen; blijft de beroepsorganisatie dat afwijzen dan ook de eis van uitsluitend gebruik van de eigen naam en niet van een uitgetreden of overleden collega. Brands haast zich te stellen dat hij geen pleidooi wil leveren; dat zij zo; maar zelfs als discussie-uitlokking gaat mij deze gedachtengang te snel en is zij te ongenuanceerd. Brands springt via de accountancy N.V. naar de accountant-commissaris, schrijver vindt het eigenlijk zonde dat de accountant, die zozeer de geschiktheid bezit de commissarisfunctie te vervullen, dat niet zou doen. Ook ziet hij hierin een verhoging van de ,standing" van het beroep via het ,aantreden in het gelid van bankiers, ex-ministers en grootindustriëlen". Als enig bezwaar onderkent Brands mogelijk tijdsgebrek. Het moet mij van het hart dat het te betreuren is dat Brands over de echte problematiek heenglijdt; noch de geschiktheid van de accountant voor de functie (zonder geschiktheid was er geen vraagstuk) noch het standing-aspect (die contacten zijn er toch wel, zij het uit een andere invalshoek) vormen daarvan de essentialia. Moge Brands' wens van verdere gedachtenwisseling dra vervuld worden

In het opstel „Enkele opmerkingen over de geschiedenis van direct costing en over een dualistische en niet-opportunistische variant daarvan" stelt Prof. Drs. R. Burgert zich ten doel Riebel's ,relative Einzelkostenrechnung" bij accountants te introduceren. Schrijver doet dit, na tegenover de algemeen geldende opvatting omtrent de Angelsaksische herkomst 
van "direct costing" te hebben gewezen op reeds bij Schmalenbach, Rummel en Schär te vinden aanknopingspunten daarvoor, alsmede op verwante gedachten bij Polak en Goudriaan. De „relative Einzelkostenrechnung" gaat uit van de relativiteit van de begrippen "Einzelkosten" en "Gemeinkosten", omdat de referentiebasis zowel gelijktijdelijk als volgtijdelijk kan verschillen, zowel voor directe vs. indirecte kosten als voor variabele vs. constante kosten. Burgert geeft een duidelijke uiteenzetting van de door Riebel ontworpen methode van kostenverrekening, welke hij op basis van de kritiek op D.C. door Van der Schroeff wèl dualistisch doch niet opportunistisch noemt. Overigens stelt schrijver zich kritisch tegenover Riebel's methode op; enerzijds wordt diens dekkingsbijdrage-rekening een nuttig middel geacht voor bepaalde beleidsbeslissingen, met name voor korte termijn vraagstukken; voor lange termijn beslissingen blijft echter de integrale kostencalculatie z.i. onontbeerlijk.

Op het voorgaande sluit het opstel van Drs. Th. J. van Dijk "Bedrijfseconomie en ondernemingsbeslissingen" goed aan. Schrijver stelt de integrale benadering van kosten en resultaat naast de differentiële benadering daarvan; de eerste blijft onontbeerlijk voor de weergave en beoordeling van het gehele bedrijfsbeleid over langere perioden, zowel ex ante als ex post; de tweede is echter geboden wanneer het gaat om het nemen van afzonderlijke beleidsbeslissingen.

Deze conclusie baseert schrijver op de al dan niet uit te schakelen invloed van beslissingen in het verleden; deze uitschakeling zou onjuist zijn b.v. bij de beoordeling van het totale beleid over een gegeven jaar; bij de te maken keuze uit alternatieven bij nieuwe beslissingen zal echter in de eerste plaats naar de daardoor veroorzaakte additionele offers en baten gezien moeten worden. $\mathrm{Bij}$ de verdere uitwerking wordt aandacht besteed aan beslissingen bij onderbezetting, aan assortimentsbepaling bij volle bezetting met inachtneming van „knelpunten" in de ,know-how" sector en aan investeringsselectie; allemaal problemen waarin differentiële calculatie-methoden een belangrijke rol spelen. Schrijver onderstreept zijn visie door te stellen dat de bedrijfseconomische analyse slechts mede betekenis heeft voor het actuele ondernemersbeleid, wanneer die analyse wordt gezien als ,toerekening van resultaten aan duidelijk gedefinieerde beslissingen". In laatstgenoemde zinsnede (na de komma) mis ik (nogmaals) het woordje „mede”.
Drs. A. C. M. van Kneep houdt de lezer van zijn opstel "Commercieel onderzoek en bedrijfsinterne informatie" voor, dat de zich van marktanalyse, via markt-onderzoek, tor commercieel onderzoek ontwikkeld hebbende activiteit te vlug gericht wordt op „field research" of op ,desk research" van externe gegevens. Schrijver onderstreept dat extern onderzoek eerst zin krijgt, nadat ,desk research" van interne commerciële informatie heeft plaats gevonden; slechts dan kent men de concrete situatie waarop aanvullende externe onderzoekingen zo nodig kunnen worden geënt. Schrijver werkt het interne marktonderzoek verder uit. $\mathrm{Hij}$ besluit met de zeker noodzakelijke vingerwijzing dat de vastlegging van de basis-informatie in het bedrijf mede gericht moet zijn op de behoeften van de commerciële beleidsvoering, waartoe samenspraak tussen administratieve en commerciële deskundigen noodzakelijk is.

In het opstel "Hoe diep is eigenlijk de financiële put der Verenigde Natics?" gunt Drs. $P$. C. J. Kien de lezer een blik in de meer door wereldpolitieke dan economische overwegingen beïnvloede financieringsproblematiek en de daarmee samenhangende ondoorzichtige verslaglegging van de V.N. Aangezien de te financieren activiteit voornamelijk bestond uit de "vredesmache" in Gaza en de Sinaiwoestijn, is na het verschijnen van dit opstel de oorzaak van de financiële moeilijkheden door de Secretaris-Generaal der V.N. radicaal weggenomen, waarmede althans één probleem tot oplossing werd gebracht.

Drs. N. L. Ruizendaal behandelt „De financiering bij de Nederlandse ondernemingen sinds 1921". Uitgangspunt voor de beschouwingen vormt een aantal $\mathrm{kwantitatieve} \mathrm{ge-}$ gevens over netto-investeringen enerzijds en reserveringen plus aandelen-emissies anderzijds. Schrijver toont dan aan dat de financiering met eigen vermogen in de periode 19211939 relatief groter was dan in de periode 1948-1965, n.l. $74 \%$ tegenover $45 \%$. Daarbij dient echter bedacht te worden dat Ruizendaal's netto-investeringen niet alleen vaste activa, maar ook voorraden en onderhanden werk omvatten, zodat de relatieve positie van het eigen vermogen niet slechts wordt afgemeten aan de totale behoefte aan lang vermogen, doch aan de vermogensbehoefte inclusief $\mathrm{fi-}$ nancieringsmiddelen als leverancierscrediet e.d. R. doet dit bewust en dat is zijn goed recht, maar of hij op deze gegevens zijn conclusie van de afgenomen betekenis van de winstinhouding als middel om in de vermogensbehoefte te voorzien mocht baseren is 
aan twijfel onderhevig. Dit geldt temeer, nu de omvang van de vermogensbehoefte na de vorlog in absolute zin zo onvergelijkelijk veel groter is geworden, dat zelfs een relatieve achteruitgang van de financiering met eigen vermogen niet tot de conclusie mag voeren, dat nu ook de betekenis daarvan duidelijk is afgenomen. Het vorenstaande doet overigens niets af aan de verdiensten van R.'s beschouwingen over de na-oorlogse omstandigheden, die het aantrekken van vreemd vermogen stimuleerden (zoals wijziging in het fiscale stelsel en de voortschrijdende inflatie), alsmede over de morieven voor en de zich in de loop van de tijd wijzigende achtergronden van de intcrne financiering. Terecht besluit R. zijn opstel met de stelling, dat de financiering van de onderneming zich heeft aangepast en in de toekomst zal aanpassen aan de tijdsomstandigheden.

Drs. J. van der Velden geeft in zijn bijdrage een globaal overzicht van "de taak van de accountant bij de voorbereiding en uitvoering van samenwerkingen tussen ondernemingen". Schrijver onderscheidt fasen in de taakvervulling, die de indruk wekken bedoeld te zijn als na elkaar te worden aangepakt. Ik neem echter aan, dat hier eerder sprake is van een systematiek van behandeling door de auteur, dan van realiter elkaar opvolgende verrichtingen; met name fase 2 (een technische, commerciële, financiële, fiscale, administratieve, organisatorische en economische analyse van het samenwerkingsproject) lijkt mij voor een belangrijk deel onuitvoerbaar, wanneer niet tevens de op gelijke grondslagen gebrachte cijfers der samenwerking-zoekende bedrijven, voortvloeiende uit fase 3 (vaststelling der richtlijnen voor een uniforme waardebepaling), beschikbaar zijn, Van der Velden beperkt zich blijkens de titel van zijn opstel tot de taak van de accountant; die taak wordt in vogelvlucht stellig niet onverdienstelijk aangegeven. Toch kan de auteur niet vermijden hier en daar de verantwoordelijkheid van de accountant te noemen of aan te duiden. $\mathrm{Zo}$ schrijft Van der Velden dat de accountant, als lid van een voorbereidingscommissie, erop moet toezien dat de economische analyse tor een betrouwbaar beeld leidt van hetgeen men door samenwerking wenst te bereiken en dat hier ,een grote verantwoordelijkheid voor de accountant" ligt (fase 2). Ten aanzien van de uniformering van waarderingsgrondslagen beperkt schrijver zich tot de stelling, dat „het tot elkaar brengen van partijen" de taak van de accountant is (fase 3). Terzake van de waardering van de ondernemingen zelve (fase
4) onderscheidt Van der Velden waardering door de accountant of door ,de administraties van de ondernemingen zelf"; in het laatste ge$\mathrm{val}$ is er dan sprake van een ,investigation". Het is jammer dat deze problematiek niet goed uit de verf gekomen is.

"Grootwinkelbedrijf en Computers" is de titel van de bijdrage van Drs. C. Brevoord, waarin een bijzonder interessante uiteenzetting wordt gegeven van een zeer complexe en flexibele informatiebehoefte, waaraan door een goed voorbereide computer-toepassing adequaat kan worden voldaan. Het is echter al gauw duidelijk, dat de deskundigen (en dus ook de auteur) weliswaar nauwkeurig kunnen aangeven, hoe onder bepaalde omstandigheden en voorwaarden een optimaal informatiepatroon kan worden bereikt en welke voor de beleidsvoering van groot gewicht zijnde gegevens alsdan kunnen worden verkregen, doch dat men in de praktijk daar - ook in de Verenigde Staten - nog ver van verwijderd is. Op een symposium van de Internationale Vereniging van Grootwinkelbedrijven werd recentelijk de conclusie bereikt, naar Brevoord aan het slot van zijn artikel zegt, dat automatisering veel gecompliceerder en tijdrovender is dan het dikwijls (door de fabrikanten) wordt voorgesteld. Het feit dat de auteur de oorzaken van het achterblijven kent en weergeeft, biedt overigens het uitzicht, dat men deze te enigertijd weet te overwinnen; terecht noemt schrijver automatisering ,een proces, dat jaren van ingespannen creatieve arbeid vergt en dat slechts dan kan slagen, wanneer het hele bedrijf, inclusief de leiding, er rijp voor is".

Dr. C. A. Buningh beschrijft „Recente ontwikkelingen rondom de organisatiestructuur in de onderneming". Tegen de achtergrond yan te constateren trends in het sociaal-economisch klimaat, in de attitude van de mens en in de ondernemingsvorm en -omvang behandelt de auteur de ontwikkeling van het "management", alsmede de inpassing daarin van de planning- en signaleringstechnieken. Deze technieken acht B. essentieel voor de overdracht en realisatie van het beleid; veel belangrijker dan zeer gedetailleerde organisatie-schema's of functie- en taakbeschrijvingen, die immers snel verouderd zijn en frustrerend werken op de lagere echelons. Hij gaat daarom uitvoerig in op de vraag, hoe de in gebruik zijnde organisatie-vormen passen in de ontvouwde gedachten inzake "management" en planning. Besproken worden achtereenvolgens de lijn-, functionele, staf-, oligarchische, 
democratische en horizontale organisatie, met de daaraan verbonden voor- en nadelen. Er zijn blijkbaar geen organisatievormen, die zo duidelijk boven andere uitsteken, dat een algemene ontwikkeling in éen bepaalde richting geconstateerd kan worden; de auteur meent integendeel "dat dynamiek een van de belangrijkste grondprincipes van het organiseren is". "De externe accountant en bet financieringsbeleid in de onderneming" is de titel van de bijdrage van Drs. R. A. M. van der Hart. Schrijver behandelt allereerst de adviesfunctie. $\mathrm{Na}$ als eisen waaraan de adviseur moet voldoen te hebben genoemd: een redelijke theoretische kennis, een ruime ervaring en objectiviteit, concludeert v. d. H. dat de accountant niet alleen aan deze eisen voldoet, doch vrijwel de enige is die - mede op grond van zijn specifieke kennis van het bedrijf en zijn brede ervaring - daarvoor beschikbaar is. V. d. H. constateert cen kloof tussen de financieringstheorieën en de financieringspraktijk; hij citeert daartoe Diepenhorst en Willems: „Het formuleren van een algemeen toepasbaar optimalisatiecriterium schijnt een vrijwel onmogelijke opgave". Men kan zich echter afvragen of $\mathrm{V} . \mathrm{d}$. $\mathrm{H}$. dit van de financieringstheorie mag verwachten? Het doet overigens deugd, dat V. d. H. waarschuwt tegen het van de overkant van de Oceaan overgewaaide overtrokken gebruik van kengetallen (ratios); hij brengt hun betekenis tot juiste proporties terug.

Met betrekking tot de controlerende functie pleit schrijver voor een goede voorlichting over het financieringsbeleid in de publikaties van de onderneming, alsmede voor duidelijke analyses in het accountantsrapport voor de beperkte kring.

Drs. A. Hemelaar behandelt het zeer actuele problecm "Administratieve automatisering en de accountant". Met betrekking tot de adviserende functie blijkt $\mathrm{H}$. zich te beperken tot de (individuele) accountant die zich met de controle bezighoudt; hij laat zodoende interne specialisatie binnen accountantskantoren voor zijn conclusie buiten aanmerking; hij constateert dan dat de automatisering de adviserende functie van de controlerende accountant op administratief-organisatorisch terrein terugdringt. Toch ziet $H$. de interne verbijzondering wel en pleit dan ook voor samenwerking van specialisten bij grotere kantoren met kleine(re) accountantskantoren. Terzake van de controlerende functie verlangt schrijver vroegtijdige medewerking van de accountant ter wille van de inbouw van de interne controle; hij zal hier eisen moeten stellen. Wat de uitvoering van de controle betreft komen de aspecten „om de computer heen" en „door de computer" ter sprake. Duidelijk blijkt dat de eerste methode in de meeste gevallen nog steeds tot de mogelijkheden behoort; de wcede - veel moeilijker - methode komt dan ook slechts in vage aanduidingen aan de orde. Dit $\mathrm{kan}$ de auteur niet euvel worden geduid; aan de wenselijkheden en mogelijkheden daarvan zal nog veel denkwerk moeten worden besteed.

Drs. R. C. A. Jongstra behandelt "Enkele vaktechnische aspecten van bet gebruik van steckproeven bij de accountantscontrole". Terecht stelt schrijver dat de mathematische steekproef de voorkeur verdient boven positieve detailcontrole bij ondernemingen waar de interne controle uitstekend is georganiseerd. Daarnaast behandelt $\mathrm{J}$. de steekproef bij cijferbeoordelingen m.b.t. bruto-winstpercentages, kortingen e.d., welke niet in de plaats van positieve detailcontrole komt, zodat de voorwaarde van ,een interne controle op hoog niveau" nu niet gesteld behoeft te worden. Ik vraag mij af, of de voorwaarde van een perfecte interne controle bij steekproeftoepassing wel op goede gronden steunt; "perfect" en "uitstekend georganiseerd" zijn grote woorden met een geringe realiteitswaarde. Overigens ben ik het geheel eens mct de auteur wanneer hij stelt, dat toetsing van de interne controle niet met mathematische steekproeven behoort te geschieden; al blijft het voor mij een probleem op welke wijze de toetsing van de werking van de interne controle dan wel doeltreffend kan plaats vinden. Ten slotte behandelt $J$. de steekproeftechniek in gevallen, waarin ,de accountant op goede gronden een controleplan opstelt, waar hij behalve voor enkele balanscontroles geheel steunt op de interne. controle". Het blijkt dat de auteur denkt aan grote ondernemingen, waar de interne controle-taken zijn verbijzonderd en ondergebracht in cen afzonderlijke afdeling: De op deze interne controle toe te passen cijferbeoordeling wil J. nu via mathematische steekproeven laten plaats vinden; hij noemt dit een ,zwaardere toetsing" van de interne controle, noodzakelijk omdat daarop door de accountant vrijwel uitsluitend wordt gesteund. Schrijver spreekt niet van interne accountantscontrole en van een aanvullend onderzoek daarop; indien hij dit ook niet bedoelt, lijkt zijn conclusie op zijn zachtst nogal vreemd.

Drs. E. L. Th. Laterveer wijdt zijn opstel aan de problematiek rond de verslaggeving van 
naamloze vennootschappen, onder de titel „De accountant - een wereldhervormer?" $\mathrm{Bij}$ de bespreking van ontwikkelingen in het buitenland noemt de auteur in de USA de S.E.C., die hij - ten onrechte - een door het bestuur van de effectenbeurs in het leven gerocpen commissie noemt, het „Security and Exchange Committee". Deze commissie heet "Securities and Exchange Commission"; ze is een zuivere overheidsinstelling, gebaseerd op de "Securities and Exchange Act" van 1934. De daarna genoemde rol van het American Institute of Accountants (dit heet: American Institute of Certified Public Accountants; afgekort AICPA) is ook incompleet; ,de bekende recommendations" zijn al sinds enige tijd opgevolgd door de „APB-opinions" (Accounting Principles Board); afwijking daarvan moet in de accountantsverklaringen worden vermeld! Terzake van het Duitse Aktiengesetz 1965, in werking getreden op 1 jan. 1967 zegt schrijver dat daarin een poging is gedaan velerlei moderne bedrijfseconomische begrippen en grondslagen op te nemen; het lijkt mij dat deze poging dan weinig geslaagd mag heten. Gaarne sluit ik mij overigens aan bij de stelling van de auteur, dat te veel willen regelen tot verarming en verstarring moet leiden. $\mathrm{Na}$ de publikaties en activiteiten in Nederland te h.bben nagegaan, beantwoordt L. de vraag naar de rol van de public accountant te dezen aanzien als volgt: "Geen wereldhervormer of nieuwlichter dus, maar een stimulerend adviseur, zich bewust van het maatschappelijk belang van zijn functie, eens te meer in de nieuwe constellatie".

"Het vrije beroep van de accountant" is het onderwerp van Dr.W.F. Nederstigt's bijdrage. N. meent dat het bij een vrij beroep niet primair gaat om juridische of economische vrijheid, doch om vaktechnische vrijheid. „In vele gevallen is de beroepsmatige vrijheid ook in een juridisch niet onafhankelijke situatie voldoende gewaarborgd", zegt schrijver; als voorbeeld noemt hij de huisarts in dienst van een grootbedrijf en de psycholoog in dienst van een stichting. Aan dit betoog ontneemt de auteur echter zelf een groot deel van zijn kracht, door te stellen, dat zulk een situatie van de werkgever voldoende inzicht en van de beroepsbeoefenaar voldoende verantwoordelijkheidsbesef en ,karakter" vraagt! De begrippen „funcrionele afhankelijkheid en onafhankelijkheid" noemt $N$. in het gehee] niet. $\mathrm{Na}$ beklemtoond te hebben dat het vertrouwen zijn basis vindt in specifieke deskundigheid en de persoonlijke verantwoordelijk- heid van de beroepsbeoefenaar voor het resultaat van zijn werk, gaat N. verder op de beroepsethiek in; hij behandelt reclame, honoreringsbasis, provisie en de institutionalisering. De auteur gaat vervolgens zijn tot dusver algemeen gehouden betoog toespitsen op het accountantsberoep en belicht dan de bijzondere relatie tussen zijn beoefenaren en de - naast de opdrachtgever een grote rol spelende - "anonieme derde". Wie nu met belangstelling uitkijkt naar een uitlating van schrijver over zijn opvattingen terzake van de vrije beroepsuitoefening van de interne accountant (naar analogie van de besproken huisares en psycholoog) komt bedrogen uit; daarover wordt gezwegen. N. gaat op een heel ander vraagstuk in, n.l. de mate van institutionalisering, die hem voor het accountantsberoep aanvaardbaar voorkomt. Schrijver komt dan tot enkele markante uitspraken, die mij overigens soms met elkaar in tegenspraak lijken. N. beargumenteert het nut van grote accountantskantoren; verdedigt voorts de grootstmogelijke vrijheid van de individuele accountant daarin (zonder onderscheid naar maatschapslid of in dienstbetrekking); ziet slechts grond voor vrijheidsbeperking , in organisatorisch opzicht" binnen de maatschap, doch niet in vaktechnisch opzicht; spreekt in dat verband slechts van "prijsgeven van eigen inzicht" als ongewenst verschijnsel, doch besteedt nauwelijks aandacht aan elementen als het te zamen bewaken van kwaliteitsovereenstemming als positief verschijnsel; noemt collectieve verantwoordelijkheid een contradictio in terminis; meent overigens dat verdere ontwikkeling van het beroep in de richting van bedrijfsmatige exploitatie de openbare functie niet in gevaar brengt, om tenslotte dit weer terug te nemen voor de functie van vertrouwensman van de cliënt. N.'s behandeling is ongetwijteld origineel, al lijkt ze mij niet in elk opzicht consequent doordacht. Wij citeren echter gaarne en met volledige instemming: „Noch de voorschriften van de beroepsorganisatie, noch de richtlijnen van het kantoor waaraan de accountant is verbonden, maken zijn persoonlijk eindoordeel overbodig".

De bundel wordt besloten met een opstel van Dr. H. L. Drost over "De belastingheffing, voorheen en thans, bij de beëindiging van een bedrijfs- of beroepsuitoefening".

Schrijver geeft in kort bestek een goed overzicht van hoe het was (Wet I.B. 1914, Besluit I.B. 1941) en hoe het nu is (Wet I.B. 1964), waarmee ook het fiscale aspect een plaats in dit jubileum-boek verkreeg. 
Paul Deneffe

\section{DISTRIBUTIE EN CONSUMENT - evolutie en prognose}

Serie Bedrijfseconomische Bibliotheek no. 1. Standaard Wetenschappelijke Uitgeverij, Antwerpen. Voor Nederland: H. E. Stenfert Kroese N.V., Lciden 1966, 244 blz., 71 tabellen. Prijs gebonden f 20,- .

\section{door Dr. N. Tiernstra}

Paul D. C. Deneffe, doctor in de toegepaste economische wetenschappen van de Universiteit te Leuven en doctor in de ,économie ouvrière et socialc' van de Universiteit van Parijs, is docent aan de Universiteit te Leuven en adjunct-directeur van het Vervolmakingscentrum voor Bedrijfsleiding. Hij heeft gedurende twce perioden gestudeerd en onderzoek verricht in de Verenigde Staten en is in Belgie lid van verschillende colleges die activiteiten verrichten op de terreinen van distributic en produktiviteitsbevordering.

De studic, die gebaseerd is op beschikbaar statistisch materiaal, heeft als object het verband tussen de na-oorlogse evolutic van de distributie en de veranderingen in de consumptie-determinanten in de Verenigde Staten van Noord-Amerika (tot 1960) en in België, Frankrijk, Groot-Brittannië, Nederland en West-Duitsland (tot 1964).

De titcl is - zoals de auteur overigens ook laat uitkomen - voor de inhoud van het boek te weids. Feitelijk gaat het om de distributie van voedingsmiddelen op het nivcau van de detailhandel, en dan nog vaak in het bijzonder om die van kruidenicrswaren. De motivering van deze bepcrking - in het inleidende hoofdstuk - had overigens wel wat meer geadstrueerd mogen worden. Onder evolutie verstaat de auteur zowel de groeiende belangstelling voor genocmde aktiviteit als de veranderingen die zich in de distributic zelf voordocn. Bij het woord „prognose" moet de lezer niet denken aan de resultaten van kwantitatief onderzockingswerk zoals dat bijvoorbee!d door het Centraal Planbureau wordt verticht. Deneffe wil niets anders doen dan een aantal tendenties in kwalitaticve zin doortrekken.

Een van de voornaanste uitgangspunten van Deneffe is dat de evolutie in de Verenigde Staten sinds cen dertigtal jaren in de ecrste plaats betrekking heeft op aanpassingen aan de veranderende consumptievoorwaarden.

Deze gedachtengang lijkt voor een welva- render wordende westelijke samenleving in haar algemeenheid wel juist.

Bij het lezen van deel I: „Het wezen van de Distributie", heb ik het wel wat mocilijk gehad. De autcur oriënteert zich aan de gedachten van Haccoû en Drecsmann over het wezen van de handel. Hij acht een omschrijving van de distributie als, ,ceel van de handel" in termen van ,geledingen of instellingen" te statisch, gegeven de vele "verticale" aktiviteiten van producenten, groot-en kleinhandel. Wanncer dan, naar Verdoorn, wordt vastgesteld dat de distributieaktiviteiten in de praktijk niet meer volkomen samenvallen met de distributieorganen en de distributic wordt gedefiniëerd in termen van aktiviteiten en vervolgens wordt ingegaan op een zekere „verspilling” dic vertegenwoordigd zou zijn in de distributickosten, en weer langs andere weg de betckenis van de distributie wordt benaderd als functie van de behoefte van de individuele onderneming, gaat het stuk m.i. wel wat in de mist.

Wat gemakkelijker maakt de auteur het zich wanneer hij de groeiende betekenis van de distributic toelicht, ondermeer - en is dat wel zo gelukkig? - aan de hand van een (op twee hypothesen gebasecrde!) prognose van de stijgende werkgelegenheid in deze sector van 1955 op 1970 van de autcurs Jefferys en Knee.

Deel II behandelt de evolutie van de distributic in de Verenigde Staten. Interessant zijn de gegevens omtrent de detailhandelsomzetten in verschillende typen stedelijke agglomeraties en op het platteland. Het vraagstuk van de ontwikkeling van de shoppingcenters versus de toekomst van het detailhandelsapparaat in stadskernen verdient echter een veel genuanceerder behandeling dan hier is geschied. De autcur heeft zich ongetwijfeld veel mocite getroost om het proces toe te lichten aan de hand van gegevens over omzetverloop en marktaandelen, maar ik kan mij voorstellen dat de belangstellende lezer vooral vraagt naar het waarom van deze uitkomsten.

Ten slotte laat de auteur - in een eigen terminologie - een aantal gegevens volgen omtrent de horizontale samenworking en integratie in de levensmiddelensector. In 1964 bedroeg het marktaandeel van de zogenaamde onafhankelijke kruidenjersvestigingen nog maar 9 procent. Het marktaandeel van de op de ecn of andere wijze georganiseerde zelfstandige ondernemer stijgt zeer snel. De auteur verwacht een versnelde horizontale 
marktconcentratie, die dan ook de mogelijkheid tot integratie in belangrijke mate zou verhogen.

Als verklarende factoren voor de ontwikkeling van het distributieapparaat onderscheidt Deneffe: 1 . primaire consumptiedeterminanten: demografische en inkomensfactoren (geen opleiding, $T$ ); 2 . secundaire determinanten: veranderingen in de keuze van de woonplaats, de vervoermiddelen, de tijdsbesteding enz. als gevolg van $1 ; 3$. de koopgewoonten, die resulteren uit 1 en 2 . Tegen dit schema kunnen vele bezwaren worden ingebracht. De voornaamste bezwaren zijn dat het schema te simpel is, dat bepaalde secundaire determinanten niet per se uit primaire determinanten behoeven voort te vloeien, en dat de ten aanzien van het koopgedrag in belangrijke mate invloed uitoefenende samenlevingsverschijnselen, belevings- en waarderingsfactoren, alsmede de ondernemingsaktiviteiten, er geen plaats in hebben.

Deze opmerkingen doen overigens niets af van het feit dat de tekstgedeelten die betrekking hebben op het koopgedrag en bepaalde achterliggende invloeden, bepaald de interessantste zijn uit het werk. Ik heb mij overigens afgevraagd waarom in de paragraaf over de secundaire determinanten, de consumptieve bestedingen worden behandeld. Het gaat toch om hetgeen bepalend is voor de consumptieve bestedingen en om de plaatsen waar deze terecht komen. Op de gegevens zelf behoeft weinig commentaar te worden gegeven en de conclusies die uit dit materiaal kunnen worden getrokken, zijn in het algemeen wel bekend. Het is mij niet duidelijk waarom de auteur op pag. 86 opmerkt dat het feit, dat de gezinnen in de voorsteden groter en jonger zijn dan die in het stadscentrum, gunstig is voor de detailhandel aldaar en voor de voedingshandel in het bijzonder. Van een oudere bevolking van gelijke omvang zijn, volgens de Wet van Engel, de uitgaven voor voedingsmiddelen naar verhouding het hoogst. Daartegenover staat dat hun inkomens naar verhouding lager kunnen zijn, maar in de jongere gezinnen, met name in de periode van de zgn. achievement, nemen de uitgaven voor voedingsmiddelen relatief geruime tijd af en dat is geen plezierige situatie voor het gevestigde distributieapparaat. Bovendien zijn er duidelijke indicaties dat de uitgaven aan voedings- en genotmiddelen in kleinere gezinnen relatief het grootst zijn. Deneffe besteedt ook aandacht aan de gevolgen van de toenemende tewerkstelling van vrouwelijke arbeidskrachten. Ik zou hierbij (aanvullend) willen opmerken dat blijkens de zevende Consumer Buying Habits Study van Dupont de Amerikaanse huisvrouw gemiddeld nog altijd per winkelbezoek $26 \mathrm{mi}-$ nuten in een Amerikaanse supermarket verblijft en dat slechts ca. $37 \%$ van de huisvrouwen in het bezit is van een boodschappenlijstje. Een recent onderzoek van Intertest in de Bondsrepubliek heeft uitgewezen dat tussen 12 en 17 uur een gelijk percentage (59) van de wel en niet beroepsmatig werkende huisvrouwen winkelt. Enkele opmerkingen over het concentratieverschijnsel, de aankopen op impuls en de aankopen op krediet besluiten dit tekstgedeelte. Het is jammer dat geen duidelijke definitie van het begrip impulsaankopen wordt gegeven. Zonder een dergelijke definitie kan men met dit begrip wel alle kanten op. Ongeveer $50 \%$ van de aankopen in supermarkten zou niet gepland zijn. Zo gesteld is het niet helemaal juist. Over de belangstelling voor de prijsfactor (blz. 94 en 95) had m.i. uitvoeriger en meer genuanceerd moeten worden gerapporteerd. Er is op dit gebicd thans wel wat goede literatuur beschikbaar.

Deel III behandelt volgens hetzelfde patroon de evolutie van de distributie in West-Europa. Alleen wordt nu niet begonnen met een beschrijving van de ontwikkeling van het distributie-apparaat, maar volgt een descriptie van de veranderende consumptiedeterminanten. Het betrolkken hoofdstuk is overigens zeker interessant. De gegevens over de leeftijdsopbouw en de gezinssamenstelling zijn jammer genoeg zo gepresenteerd dat onderlinge vergelijking van de landen nict zo eenvoudig is. Onder de secundaire determinanten wordt weer behandeld de ontwikkeling van de procentuele samenstelling van de consumptieve bestedingen naar hoofdsectoren (de gegevens uit tabel 43 voor België kunnen niet juist zijn), de motorisering en de vestiging van de consument in de voorsteden en de tewerkstelling van vrouwelijke arbeidskrachten. De op blz. 115 afgedrukte prognose van het aantal personenwagens in 1970 is in ieder geval voor Nederland ver bezijden de werkelijkheid. Interessant zijn de (helaas nog onvoldoend gedifferentieerde) gegevens over de spreiding van de bevolking over plattelandsgemeenten en steden. De conclusies in dit deel kunnen doorgaans worden gekwalificeerd als tamelijke algemeenheden. Over de invloed van de tewerkstelling van vrouweijke arbeidskrachten, de preferentie voor koop- 
avonden, de invloed van kwaliteit en prijs, is thans wel wat bekend. De invloed van de prijsfactor kan eigenlijk niet worden afgedaan met enkele alinea's zoals op pag. 127 en 128. Vetvolgens wordt de ontwikkeling van het Westeuropese distributieapparaat besproken. De voornaamste ontwikkelingslijnen zijn in algemene zin wel bekend, maar de belangstellende lezer vindt hier aardig documentatiemateriaal bijeengebracht. In de paragraaf over de groeiende prijsconcurrentie wordt een interessant schema gegeven, maar het is jammer dat het niet consequent wordt toegepast. Ook hier geldt als algemeen bezwaar dat de achtergronden van de prijsconcurrentie zo weinig worden toegelicht. Te weinig centraal staat de toeneming van de welvaart en als consequentie daarvan de (op blz. 149 gesignaleerde) aanzuigende werking op de lonen in de distributiesector.

Terzake van de toekomstige ontwikkeling van de prijsconcurrentie worden helaas de standpunten van de consument, de producent en de wetgever te kort weergegeven. Met name over het vraagstuk van verticale prijsbinding zou wel iets meer mogen worden gezegd. Dezelfde bezwaren van de beperktheid van bchandeling gelden ook de aanpassing van de detailhandel aan de vestigingsplaats van de consument, de toenemende motorisering en de distributie in de stadscentra. Vooral de invloed van de motorisering zal genuanceerder moeten worden onderzocht dan in de regel tot dusver geschiedt. Ten slotte brengt de auteur materiaal bijeen terzake van het concentratieverschijnsel.

Het laatste deel is getiteld: „Bedrijfsbeleid en evolutie in de distributie". Als veranderende produktievoorwaarden worden genoemd de technische vooruitgang, het duurder wordende produktieapparaat, de aard van de produktie, de veranderende consumptievoorwaarden en de groeiende invloed van de consument. Er ontstaan nieuwe concurrentievormen, met name wat de auteur noemt de intergeledingenconcurrentie.

Ten aanzien van het dienstenaanbod als onderdeel van de relatie van ondernemer tegenover consument had bijzonder interessant materiaal bijeengebracht kunnen worden.

Het blijft nu echter allemaal wat hypothetisch en beknopt.

Vervolgens wordt aandacht besteed aan de relatie van onderneming en geledingen in de bedrijfskolom. In feite is de middengrote onderneming het meest aangewezen op formele samenwerking, aldus Deneffe. Het verschijnsel dat grote distributieondernemingen bepaalde afdelingen aan gespecialisecrde handelaars of ambachtslieden verhuren, wordt beschouwd als een belangrijke ontwikkeling in de Amerikaanse distributie. In de paragraaf over de distributie tegenover de gemeenschap merkt de auteur op pag. 203 op dat het opvallend is dat slechts bij uitzondering de psychologische en sociale aspecten van de dienstverlening worden benadrukt. Deneffe heeft voor dit aspect dus zeker wel oog, maar het is jammer dat het eigenlijk nergens is uitgewerkt en pas op pag. 203 duidelijk naar voren komt. Op pag. 206 betoogt de auteur tenslotte: wanneer men het primaat van de belangen van de consument bij het distributieproces aanvaardt, is de enige index die men als meting van het nut van de distributie in de maatschappij kan aanwenden, een die rekening houdt met de kwaliteit, de verscheidenheid, als de kwantiteit van de aan het individu verschafte behoeftebevrediging. De indruk van dit deel is dat het weinig concreet is en dat een aantal op zichzclf natuurlijk wel interessante algemeenheden bijeen zijn gebracht. Veel interessanter ware het geweest uit de literatuur na te gaan wat voor diverse typen consumenten nu in feite van belang is bij de koop.

Het bovenstaande overziende, moet ik opmerken dat het aantal kritische opmerkingen niet gering is. Dit vloeit in de eerste plaats voort uit de grote belangstelling voor, respectievelijk de betrokkenheid bij het door Deneffe behandelde onderwerp. Het is geen geringe taak een dergelijk boek te schrijven en de moed van de schrijver verdient dan ook grote waardering. Ondanks de beperkingen die Deneffe zich reeds bij voorbaat heeft opgelegd, is het door hem te behandelen terrein toch wel erg groot gebleken. In zeer veel gevallen moest de auteur - en dat zou ieder ander ook zijn gebeurd - volstaan met het trekken van algemene lijnen en het geven van indicaties en veronderstellingen. Het boek is gemakkelijk leesbaar geschreven, overzichtelijk en systematisch ingedeeld en zal bijzonder interessant zijn voor hen die zich willen oriënteren omtrent de distributiesector. Ook zij die al goed bekend zijn met deze sector vinden in het boek zeer veel materiaal dat op overzichtelijke wijze is samengebracht. 